\title{
The ethics of climate-induced community displacement and resettlement
}

Article

Accepted Version

Draper, J. and McKinnon, C. (2018) The ethics of climateinduced community displacement and resettlement. WIREs Climate Change, 9 (3). e519. ISSN 1757-7799 doi:

https://doi.org/10.1002/wcc.519 Available at https://centaur.reading.ac.uk/76198/

It is advisable to refer to the publisher's version if you intend to cite from the work. See Guidance on citing.

To link to this article DOI: http://dx.doi.org/10.1002/wcc.519

Publisher: Wiley

All outputs in CentAUR are protected by Intellectual Property Rights law, including copyright law. Copyright and IPR is retained by the creators or other copyright holders. Terms and conditions for use of this material are defined in the End User Agreement.

\section{www.reading.ac.uk/centaur}

\section{CentAUR}

Central Archive at the University of Reading

Reading's research outputs online 


\section{WIREs}

\section{The Ethics of Climate Induced Community Resettlement and Displacement}

\begin{tabular}{|r|l|}
\hline Journal: & WIREs Climate Change \\
\hline Manuscript ID & WCC-811.R1 \\
\hline Wiley - Manuscript type: & Focus Article \\
\hline Date Submitted by the Author: & n/a \\
\hline Complete List of Authors: & $\begin{array}{l}\text { Draper, Jamie; University of Reading, Politics and International Relations } \\
\text { McKinnon, Catriona; University of Reading, Politics and International } \\
\text { Relations }\end{array}$ \\
\hline $\begin{array}{r}\text { Choose 1-3 topics to } \\
\text { categorize your article: }\end{array}$ & \\
\hline
\end{tabular}

\section{SCHOLARONE ${ }^{m}$ \\ Manuscripts}




\section{The Ethics of Climate Induced Community Displacement and Resettlement}

\section{Abstract}

Climate-induced resettlement programmes are happening right now in places around the world where populations face high risks from climatic impacts. Burgeoning literatures are considering the ethical implications of climate change more broadly, and the ethics of migration, but the nexus between the two issues has not been given enough attention by moral and political theorists, especially with respect to climate induced community resettlement. Here, we sketch the key nodes in a debate we think should take place, which will be made even more urgent in the coming decades as climate change impacts on communities least resilient to it. 
Focus Article

The Ethics of Climate-Induced Community Displacement and Resettlement

\author{
Jamie Draper \\ Leverhulme Doctoral Scholar in Climate Justice \\ University of Reading \\ Catriona McKinnon (corresponding author), \\ Professor of Political Theory \\ Department of Politics and International Relations \\ University of Reading \\ Whiteknights \\ Reading RG6 6AA \\ c.mckinnon@reading.ac.uk
}


Climate-induced resettlement programmes are happening right now in places around the world where populations face high risks from climatic impacts, including in the Carteret Islands (Connell, 2016), Alaskan communities (Bronen and Chapin, 2013; Shearer, 2012), the Mekong Delta in Vietnam (Dun, 2013), and beyond. These resettlement projects are diverse in their causes - which include rising sea levels and increased flooding - but are unified in how they attempt to relocate groups of people from climate-related impacts, even if they are not always explicitly framed in terms of climate impacts. Such resettlement programmes should be understood as a subset of broader adaptation efforts which may be implemented when in situ adaptation is not a feasible option (UNFCCC, 2010).

Despite a burgeoning literature considering the ethical implications of climate change more broadly (e.g. Gardiner et al., 2010; Vanderheiden, 2009; Shue, 2014; Moellendorf, 2014; Gardiner, 2011; Jamieson, 2014; Arnold, 2011; McKinnon, 2012), and the ethics of migration (e.g. Carens, 2014; Cole and Wellman, 2011; Fine and Ypi, 2016; Miller, 2016), the nexus between the two issues has not been given enough attention by political theorists. Here, we sketch the key nodes in a debate we think should take place, and which will be made even more urgent in the coming decades as climate change impacts on communities least resilient to it.

Literature in normative political theory that has engaged with climate change and migration mostly has focused either on what states owe to an idealised 'climate migrant' originating in another state (Biermann and Boas, 2010; Bell, 2004; Eckersley, 2015; Byravan and Rajan, 2010), or on the distinctive questions raised by the possible disappearance of small-island states (Nine, 2010; Risse, 2009; Kolers, 2012, Ödalen, 2014; Dietrich and Wündisch, 2015; Vaha, 2015). More empirical literatures emphasise that migration in relation to climate change is a complex, multicausal phenomenon: an adaptive response to climate change which takes place within a constellation of interrelated economic, social and political factors (Black et al., 2011a; Black et al., 2011b; McLeman and Hunter, 2010; McLeman and Smit, 2006).

Concerns about the fit between idealised visions of climate migrants, and the empirical realities, are justified (Black, 2001; Wood, 2001; Hulme, 2008). A further important reason for concern which is not often registered - is that the focus on an idealised international climate migrant has made the ethics of climate-induced community-level resettlement less visible than it should be. Here, we map out some important ethical issues raised by community-level resettlement programmes by considering the values relevant to three aspects of these programmes. These are: the framing of resettlement programmes and their objectives; the procedures used in the management of resettlement; and the ideal or intended outcomes of resettlement programmes.

\section{Framing}

We are interested in how values of justice and ethics implicit in debates about resettlement provide framings for these debates, which sit alongside other framings, such as those focused on security or humanitarianism (e.g. Boas, 2015; Mayer, 2016).

Justice framings of climate-induced resettlement are diagnostic: they provide a normative lens through which issues arising in this context come into view, and can be dissected. This diagnostic work can begin by considering the nature of the damage that is likely to be faced by those being resettled in the context of climate change. In broader debates in political theory 
about distributive justice, this question refers to understanding the currency of justice. ${ }^{1}$ For example, we might conceptualise this damage in terms of overall welfare, or opportunity for welfare. Or we might focus instead on fungible or non-fungible resource losses. A different approach to these questions has been in terms of capabilities to function. For example, De Shalit (2011) has argued that in the case of permanent climatic displacement, we ought to think of the loss of a sense of place in terms of the loss of an essential functioning (in Sen's terms) because of its critical role in the formation of identity. Barnett et al. (2016) have recently called for a 'science of loss' in order to better understand what it is that people value when what they care about is imperilled by climate change.

Is there is something distinctive about relocation at a community level that puts relational goods at stake? It seems that if we were to take each individual's losses as a result of relocation and aggregate them, we would still have an inadequate understanding of the loss overall, since some goods only emerge at the community level. In tribal communities facing relocation in Alaska and Louisiana, for example, socio-cultural institutions and tribal relationships have been identified as being of central importance, and as having this distinctive character (Maldonado et al., 2013, p. 611). It is important for political theorists to be able to account for the nature of these goods. Are these relational goods reducible to individual welfare, or other individual losses? Or are they properly thought of as belonging to the community itself? (And if so, what could this mean?). This may impact on what is owed to relocated people as a matter of justice: if community losses are reducible to individual losses then it may be easier to compensate for these losses than if community losses have ethical standing independent of, and/or in addition to, individual losses.

Another issue of framing concerns the kind of justice that is envisaged. For example, if historical emissions which have caused climate change have significant moral weight then resettlement could become a matter of corrective justice, as typified in the idea of the 'polluter pays principle' which states that those who brought about a harm ought to remedy it. ${ }^{2}$ Concerns have been raised with taking a historical approach to climate justice, such as the problem of emitters being excusably ignorant before a certain point, and of emitters of the more distant past no longer being alive (e.g. Caney 2005; Gosseries, 2004; Shue, 1999; Gadiner, 2010).

How we think about historic emissions matters for framing resettlement in terms of justice. For example, in a corrective justice frame, parties liable for the displacing effects of climate change could offer just resettlement as compensation for the displacement; such parties might be countries, or even fossil fuel corporations. A compelling first thought is that liable parties ought to make resettled people as well off as they would have otherwise been, but it will never be the case that the new location will perfectly replace the home lost. We must then consider if the kind of compensation being offered is supposed to be means replacing compensation, which is compensation that allows people to pursue the same ends as before, or ends-displacing compensation, which helps those affected to pursue different ends, but which leaves them subjectively as well off as before (Goodin, 1989; Wolff, 2002).

A different way to think about relocation starts with a commitment to making those affected better off than before. On this approach, our thinking about justice derives from a broader understanding about what is owed to those affected as a matter of distributive justice. Those affected by the impacts of climate change are often the most vulnerable people in societies, living in places that are least resilient to climate impacts, and we might think that what they are

\footnotetext{
${ }^{1}$ See the discussion in Wolff (2015). Some important texts in this debate include Arneson (1989), Cohen (1989), Sen (1987), Daniels (1990) and Scheffler (2003).

${ }^{2}$ For succinct expressions of this principle, see Singer (2010, p. 190).
} 
(200, for example,
(20165-70).

owed is part of a broader account of what we owe to the worst-off people in societies in general. A 'holist' account holds that entitlements in this specific case cannot be determined without reference to a broader scheme of entitlements and obligations. The holist account has it that the baseline which is appealed to in accounts of corrective justice - that is, the state of affairs affected communities would have been in had they not been affected by climate change - is itself open for assessment as a matter of justice. ${ }^{3}$ In the case of small-island states, political theorists have made arguments concerning access to territory or relocation which derive this entitlement not from theories of compensation, but from broader accounts of access to territory (and sometimes sovereignty) found in the work of John Locke (e.g. Nine, 2010; Kolers, 2012) and Hugo Grotius (e.g. Risse, 2009). In the context of climate-induced resettlement, we might think here of frameworks which pursue both adaptation and development objectives in tandem (Sherman et al., 2016). In their practical application, the objectives of both practices may well overlap, but if there are trade-offs to be made it is important to have an account of the relationship between issues of climate justice and broader issues of distributive justice.

\section{Procedures}

An account of justice in climate-induced community resettlement requires us to consider the ways in which those affected by relocation ought to be treated in the process. There are at least two stages to consider: decision-making, and implementation. In terms of decision-making, an essential element is the participation of those facing relocation (Hugo, 2011). The specific requirements of participation in decision-making, however, are less clear.

There are a number of reasons to value participation in decision-making, one of which is that failing to recognise the communities affected as being distinctive groups with their own concerns of the kind identified earlier might generate failures of resettlement processes. Given this, are cultural needs satisfied in resettlement only if certain kinds of participatory processes are adopted (Schlosberg, 2012)? This question has bite given that many of those groups affected by relocation have histories of being marginalised and excluded as groups. In the case of Alaska, for example, many have become vulnerable as part of historic colonial 'civilising' programmes (Marino, 2012). At a basic level, effective participation may be desirable if we want resettlement programmes to 'stick'. However, this rationale rarely presents the complete picture; we often think that there are principled rather than merely practical reasons for encouraging the participation of those affected by resettlement programmes.

Such principled reasons might appeal to values intrinsic to the participatory process; for example, respect for the autonomy of those facing relocation. Resettlement will require collective decisions to be taken, and respect for autonomy can be seen to be 'basic' in the sense that it requires us to consider what kinds of decisions and decision-making procedures are consistent with taking those displaced to be self-directing agents with sovereignty over themselves. This kind of rationale focuses attention on the relevant standards for legitimate decision-making in the case of climate-induced resettlement, which will vary in their demandingness. At the most demanding end of the spectrum, we might insist that the consent of all people facing resettlement must be sought on all key aspects of the proposed resettlement. In contrast, a less demanding standard would require only a consultative approach. In order to develop standards of participation which are both theoretically defensible and practically implementable, we can refer to literatures in different domains which engage with similar questions, such as the literature concerning displacement by development (e.g. Penz, Drydyk and Bose, 2011; Drydyk, 2013). There are structural similarities between cases of climate- 
induced community resettlement and displacement by development. For example, in both cases the least powerful people in society are more likely to be affected than those with more resources, and more resilience. Genuinely participatory approaches which stress human agency, rather than technocratic or managerial solutions, have been identified as critically important in development-forced displacement relocation projects, and are of similar importance - we think - in cases of climate displacement (Wilmsen and Webber, 2015).

A further dimension of procedural legitimacy concerns justification and public reason. Philosophical treatments of these concepts generally address the justification of broader rules or principles to do with the basic design of society, but there is scope to apply ideas from this domain to procedures for resettlement. Here, we might think that in order for relocation decisions to be legitimate under circumstances characterised by disagreement, these decisions must be justified to those who are affected, in terms they could not reasonably reject. How this standard is elaborated will vary according to the understanding of public reason we adopt, but since these approaches seek to find standards of legitimacy under disagreement, they may be useful theoretical tools. ${ }^{4}$

The case of climate-induced community displacement requires us to take account of its distinctive features, such as urgency or unavoidability. This concern brings to the fore questions about how to mediate disagreements about resettlement, and other ethical constraints that might be put upon decisions. For example, if a community prefers a site for resettlement which is much less likely to satisfy their material needs than another site, how should programme administrators proceed? Should we use ethical standards external to communities to scrutinise the decision-making procedures they use, and the ways in which community representatives are chosen? Here, we need to think about the kinds of knowledge that are considered to be authoritative is constructing and implementing resettlement programmes (Adger et al., 2011). Moreover, particular attention might need to be paid to social dynamics which affect both the perceived need for relocation, and its success. For example, gendered divisions of labour may mediate the ways in which the impacts of climate change are experienced, or affect the decisionmaking capital of women in particular communities (Alston, 2013).

Programme implementation raises questions about what is owed to those being resettled in the process. Many rights-based accounts set out the goods, resources, and forms of treatment people are entitled to as a minimum (and beyond) in any society. How might these oftenabstract accounts translate into practical guidelines in the diverse and demanding circumstances of resettlement? More richly textured accounts of human well-being that go beyond rights might deliver more practical guidelines. For example, Johnson (2012, p. 317-8) points towards Nussbaum's account of the functioning of affiliation, which could yield obligations to keep families and social groups together in the relocation process.

To sum up: in elaborating procedural requirements for just climate-induced communityrelocation, theorists will need to account for the standards of participation required, and the reasons that participation might be important. Moreover, they will need to account for the context-specific concerns that arise in the case of climate change, and for the substantive requirements of treatment during implementation.

Outcomes

\footnotetext{
${ }^{4}$ Different approaches to the idea of justification and public reason will have significantly different results. For an overview of how the concept has been used, see Quong (2013). Prominent accounts of public reason include Rawls (2005), Gaus (2010), and Habermas (1998).
} 
An account of the ideal outcomes of climate-induced community-level relocation programmes is likely to appeal to the nature of the damage involved in the case of climatic displacement described above, as well as to norms about participation and autonomy in procedural justice. For example, Paavola and Adger (2006) set out four principles for the ethical requirements of fair adaptation that could be transposed into this context. And Zellentin (2010) argues for an understanding of participation which takes seriously the substantive requirements of cultural differences in the case of migration in response to climate change. Although comprehensive accounts of the ethical requirements of climate-induced community-level relocation programmes are yet to be elaborated, we can gain insight from these accounts in their nascent form when thinking about the substantive requirements on outcomes that might be set out in this context.

An under-appreciated aspect of the intended outcomes of any climate-induced community-level relocation programme will be the relations between those relocated and the new host communities with which they interact. The relation between an individual sense of identity and place has been highlighted in the context of climate change (e.g. Fresque-Baxter and Armitage, 2012; Campbell, 2010) but community-level relocation brings with it a need to reconceptualise relations to place. Political theorists have set out to reconceptualise general relationships between identity and place in the light of the changing structure of the global order (e.g. Maier, 2007; Benhabib, 2007), but in the case of community relocation in the face of climate change it will be important not to obscure the perspective of those most affected (in both displaced and host communities) by using the case of climate-induced displacement as a 'test case' for cosmopolitan hopes (Farbotko, 2010). The relations between those relocated and those they are brought into contact with will also need to be elaborated. What burdens can host communities be reasonably expected to bear? And how might both local and wider communities be brought into relations of solidarity with those being relocated? Here, it will be important to understand being relocated as agents, rather than merely as passive recipients of the beneficence of others.

In elaborating the ideal outcomes of community-level resettlement programmes it may well be important to set out the minimal requirements of justice in terms of, for example, resources or well-being. It should be clear, however, that only elaborating these standards would fail to take seriously the requirements of procedural justice in this domain, and risks treating those affected as passive recipients of benefits. Rather, participation and the self-understanding of those affected will be essential to achieving just outcomes.

\section{Conclusion}

Philosophers and political theorists have not yet substantially engaged with the diverse ethical and political issues arising in the context of community-level climate-induced resettlement, despite the increased interest in both climate ethics and the ethics of migration and displacement. Engaging with these questions will require paying particular attention to the distinctive contexts and circumstances in which these kinds of resettlement programmes occur, and to their similarities and differences with other kinds of cases which have been more thoroughly theorised. This will require scholars to engage with those working in other disciplines, particularly those working qualitatively with people most affected by the impacts of climate-induced resettlement.

We have raised questions here pertaining to the values relevant to the framing, procedures and outcomes of community-level climate-induced resettlement. There are undoubtedly many more questions which will emerge as climate-induced resettlement becomes a more pressing concern. It is our hope that this article will serve to start a broader conversation about the requirements of justice in this domain. 
Acknowledgements

This paper is part of a project on community claims-making and climate displacement at the Centre for Climate and Justice at University of Reading. The project is led by Alex Arnall, and other participants are Chris Hilson and Ruvi Ziegler. We are grateful to Chris Hilson and Rob Jubb for comments.

\section{$\underline{\text { References }}$}

Adger, W. N., Barnett, J., Chapin, F. S., \& Ellemor, H. (2011). This Must Be the Place: Underrepresentation of Identity and Meaning in Climate Change Decision-Making. Global Environmental Politics, 11(2), 1-25. https://doi.org/10.1162/GLEP_a_00051

Alston, M. (2013). Women and adaptation. Wiley Interdisciplinary Reviews: Climate Change, 4(5), 351-358. https://doi.org/10.1002/wcc.232

Arneson, R. J. (1989). Equality and equal opportunity for welfare. Philosophical Studies, 56(1), 77-93. https://doi.org/10.1007/BF00646210

Arnold, D. G. (Ed.). (2011). The Ethics of Global Climate Change. Cambridge University Press.

Barnett, J., Tschakert, P., Head, L., \& Adger, W. N. (2016). A science of loss. Nature Climate Change, 6(11), 976-978. https://doi.org/10.1038/nclimate3140

Bell, D. R. (2004). Environmental Refugees: What Rights? Which Duties? Res Publica, 10(2), 135152. https://doi.org/10.1023/B:RESP.0000034638.18936.aa

Benhabib, S. (2007). Twilight of Sovereignty or the Emergence of Cosmopolitan Norms? Rethinking Citizenship in Volatile Times. Citizenship Studies, 11(1), 19-36. https://doi.org/10.1080/13621020601099807

Biermann, F., \& Boas, I. (2010). Preparing for a Warmer World: Towards a Global Governance System to Protect Climate Refugees. Global Environmental Politics, 10(1), 60-88. https://doi.org/10.1162/glep.2010.10.1.60

Black, R. (2001). Environmental refugees: myth or reality? (New Issues in Refugee Research No. Working Paper No.34). UNHCR. Retrieved from http://www.unhcr.org/3ae6a0d00.html

Black, R., Adger, W. N., Arnell, N., Dercon, S., Geddes, A., \& Thomas, D. (2011a). Foresight: Migration and Global Environmental Change (Foresight Reports). London: The Government Office for Science. Retrieved from https://www.gov.uk/government/publications/migration-and-global-environmentalchange-future-challenges-and-opportunities

Black, R., Adger, W. N., Arnell, N., Dercon, S., Geddes, A., \& Thomas, D. (2011b). The effect of environmental change on human migration. Global Environmental Change, 21, Supplement 1, S3-S11. https://doi.org/10.1016/j.gloenvcha.2011.10.001

Black, R., Bennett, S. R. G., Thomas, S. M., \& Beddington, J. R. (2011). Climate change: Migration as adaptation. Nature, 478(7370), 447-449. https://doi.org/10.1038/478477a

Boas, I. (2015). Climate Migration and Security: Securitisation as a Strategy in Climate Change Politics. Routledge.

Bronen, R., \& Chapin, F. S. (2013). Adaptive governance and institutional strategies for climateinduced community relocations in Alaska. Proceedings of the National Academy of Sciences, 110(23), 9320-9325. https://doi.org/10.1073/pnas.1210508110

Byravan, S., \& Rajan, S. C. (2010). The Ethical Implications of Sea-Level Rise Due to Climate Change. Ethics \& International Affairs, 24(03), 239-260. https://doi.org/10.1111/j.1747-7093.2010.00266.x

Campbell, J. (2010). Climate-Induced Community Relocation in the Pacific: The Meaning and Importance of Land. In J. McAdam (Ed.), Climate Change and Displacement: Multidisciplinary Perspectives. Bloomsbury Publishing.

Caney, S. (2005). Cosmopolitan Justice, Responsibility, and Global Climate Change. Leiden Journal of International Law, 18(04), 747-775. https://doi.org/10.1017/S0922156505002992 
Gosseries, A. (2004). Historical emissions and free-riding. Ethical Perspectives, 11(1), 36-60.

Habermas, J. (1998). Between Facts and Norms: Contributions to a Discourse Theory of Law and Democracy. MIT Press.

Hugo, G. (2011). Lessons Learned From Past Forced Resettlement For Climate Migration. In E. Piguet, A. Pecoud, \& De Guchteneire (Eds.), Migration and climate change. Cambridge University Press.

Hulme, M. (2008). Climate refugees: Cause for a new agreement? Commentary on "Climate refugees: protecting the future victims of global warming" by Biermann, F. and Boas, I. Environment, 50(6), 50-54.

Jamieson, D. (2014). Reason in a Dark Time: Why the Struggle Against Climate Change Failed and What It Means for Our Future. Oxford University Press, USA.

Johnson, C. A. (2012). Governing climate displacement: the ethics and politics of human resettlement. Environmental Politics, 21(2), 308-328. https://doi.org/10.1080/09644016.2012.651905 
Kolers, A. (2012). Floating Provisos and Sinking Islands. Journal of Applied Philosophy, 29(4), 333-343. https://doi.org/10.1111/j.1468-5930.2012.00569.x

Maier, C. S. (2007). Being There: Place, Territory, and Identity. In S. Benhabib, I. Schapiro, \& D. Petranovich (Eds.), Identities Affiliations and Allegiances. Cambridge University Press. Retrieved from http://dx.doi.org/10.1017/CB09780511808487.004

Mayer, B. (2016). The Concept of Climate Migration: Advocacy and its Prospects. Edward Elgar Publishing

Maldonado, J. K., Shearer, C., Bronen, R., Peterson, K., \& Lazrus, H. (2013). The impact of climate change on tribal communities in the US: displacement, relocation, and human rights. Climatic Change, 120(3), 601-614. https://doi.org/10.1007/s10584-013-0746-z

Marino, E. (2012). The long history of environmental migration: Assessing vulnerability construction and obstacles to successful relocation in Shishmaref, Alaska. Global Environmental Change, 22(2), 374-381. https://doi.org/10.1016/j.gloenvcha.2011.09.016

McKinnon, C. (2012). Climate Change and Future Justice: Precaution, Compensation and Triage. Routledge.

McLeman, R. A., \& Hunter, L. M. (2010). Migration in the context of vulnerability and adaptation to climate change: insights from analogues. Wiley Interdisciplinary Reviews: Climate Change, 1(3), 450-461. https://doi.org/10.1002/wcc.51

McLeman, R. A., \& Smit, B. (2006). Migration as an Adaptation to Climate Change. Climatic Change, 76(1-2), 31-53. https://doi.org/10.1007/s10584-005-9000-7

Miller, D. (2016). Strangers in Our Midst: The Political Philosophy of Immigration. Cambridge, Massachusetts: Harvard University Press.

Moellendorf, D. (2014). The Moral Challenge of Dangerous Climate Change: Values, Poverty, and Policy. Cambridge University Press.

Nine, C. (2010). Ecological Refugees, States Borders, and the Lockean Proviso. Journal of Applied Philosophy, 27(4), 359-375. https://doi.org/10.1111/j.1468-5930.2010.00498.x

Ödalen, J. (2014). Underwater Self-determination: Sea-level Rise and Deterritorialized Small Island States. Ethics, Policy \& Environment, 17(2), 225-237. https://doi.org/10.1080/21550085.2014.926086

Paavola, J., \& Adger, W. N. (2006). Fair adaptation to climate change. Ecological Economics, 56(4), 594-609. https://doi.org/10.1016/j.ecolecon.2005.03.015

Penz, P., Drydyk, J., \& Bose, P. S. (2011). Displacement by Development: Ethics, Rights and Responsibilities. Cambridge University Press.

Quong, J. (2013). Public Reason. In E. N. Zalta (Ed.), The Stanford Encyclopedia of Philosophy (Summer 2013). Metaphysics Research Lab, Stanford University. Retrieved from https://plato.stanford.edu/archives/sum2013/entries/public-reason/

Rawls, J. (2005). Political Liberalism. Columbia University Press.

Risse, M. (2009). The Right to Relocation: Disappearing Island Nations and Common Ownership of the Earth. Ethics \& International Affairs, 23(03), 281-300. https://doi.org/10.1111/j.1747-7093.2009.00218.x

Scheffler, S. (2001). Boundaries and allegiances: problems of justice and responsibility in liberal thought. Oxford University Press.

Scheffler, S. (2003). What is Egalitarianism? Philosophy \& Public Affairs, 31(1), 5-39. https://doi.org/10.1111/j.1088-4963.2003.00005.x

Schlosberg, D. (2012). Climate Justice and Capabilities: A Framework for Adaptation Policy. Ethics \& International Affairs, 26(4), 445-461. https://doi.org/10.1017/S0892679412000615

Sen, A. (1987). Equality of What? In J. Rawls \& S. M. McMurrin (Eds.), Liberty, Equality, and Law: Selected Tanner Lectures on Moral Philosophy. University of Utah Press.

Shearer, C. (2012). The political ecology of climate adaptation assistance: Alaska Natives, displacement, and relocation. Journal of Political Ecology, 19, 174-183. 
Sherman, M., Berrang-Ford, L., Lwasa, S., Ford, J., Namanya, D. B., Llanos-Cuentas, A., ... IHACC Research Team. (2016). Drawing the line between adaptation and development: a systematic literature review of planned adaptation in developing countries: Drawing the line between adaptation and development. Wiley Interdisciplinary Reviews: Climate Change, 7(5), 707-726. https://doi.org/10.1002/wcc.416

Shue, H. (1999). Global Environment and International Inequality. International Affairs (Royal Institute of International Affairs 1944-), 75(3), 531-545.

Shue, H. (2014). Climate Justice: Vulnerability and Protection. Oxford University Press.

Singer, P. (2010). One Atmosphere. In S. M. Gardiner, S. Caney, D. Jamieson, \& H. Shue (Eds.), Climate Ethics: Essential Readings. Oxford: Oxford University Press.

UNFCCC (Climate Change Secretariat). (2010). Enhanced Action on Adaptation. Retrieved from http://unfccc.int/resource/docs/2010/cop16/eng/07a01.pdf\#page $=4$

Vaha, M. E. (2015). Drowning under: Small island states and the right to exist. Journal of International Political Theory, 11(2), 206-223. https://doi.org/10.1177/1755088215571780

Vanderheiden, S. (2009). Atmospheric Justice: A Political Theory of Climate Change. Oxford University Press.

Wilmsen, B., \& Webber, M. (2015). What can we learn from the practice of development-forced displacement and resettlement for organised resettlements in response to climate change? Geoforum, 58, 76-85. https://doi.org/10.1016/j.geoforum.2014.10.016

Wolff, J. (2002). Addressing Disadvantage and the Human Good. Journal of Applied Philosophy, 19(3), 207-218. https://doi.org/10.1111/1468-5930.t01-1-00216

Wolff, J. (2015). Equality and Social Justice. In C. McKinnon (Ed.), Issues in Political Theory (3rd ed.). Oxford: Oxford University Press.

Wood, W. B. (2001). Ecomigration: Linkages between Environmental Change and Migration. In A. R. Zolberg \& P. Benda (Eds.), Global Migrants, Global Refugees: Problems and Solutions. Berghahn Books.

Zellentin, A. (2010). Climate Migration. Cultural Aspects of Climate Change. Analyse \& Kritik, $32(1), 63-86$. 